\title{
Effects of epidermal growth factor, interleukin 1 and nitric oxide on prostaglandin production by guinea-pig uterus
}

\author{
J. E. Keeble* and N. L. Poyser ${ }^{\dagger}$ \\ Division of Biomedical and Clinical Laboratory Sciences, The University of Edinburgh, \\ Hugh Robson Building, George Square, Edinburgh EH8 9XD, UK
}

Initial experiments in the present study investigated the effects of epidermal growth factor (EGF), interleukin $1 \beta$ (IL-1ß) and sodium nitroprusside (a nitric oxide donor) on the output of prostaglandins from guinea-pig uterus on day 7 of the oestrous cycle. Superfusion of day 7 guinea-pig uterus in vitro with either EGF or sodium nitroprusside increased the output of $\mathrm{PGF}_{2 \alpha}$ and 6-keto- $\mathrm{PGF}_{1 \alpha}$, but not of $\mathrm{PGE}_{2}$. IL-1 $\beta$ had no effect on the output of these three prostaglandins. EGF still increased the output of $\mathrm{PGF}_{2 \alpha,}$ but did not increase the output of 6-keto- $\mathrm{PGF}_{1 \alpha}$ in a calciumdepleted superfusate. Subsequent experiments investigated the effect of sodium nitroprusside on contractile activity of day 7 guinea-pig uterus. Basal spontaneous activity of both the intact uterus and isolated myometrium superfused in vitro was low. Sodium nitroprusside increased the contractile activity of these tissues two- to fourfold. EGF did not affect the contractile activity of the uterus, indicating that sodium nitroprusside-induced contractions are not due to increased prostaglandin production. Overall, the findings indicate that EGF and nitric oxide may act as mediators in the mechanism by which oestradiol acting on a progesterone-primed uterus stimulates the increase in $\mathrm{PGF}_{2 \alpha}$ production by the guineapig uterus necessary for luteolysis. Nitric oxide may increase the spontaneous activity of the uterus when this activity is low.

\section{Introduction}

$\mathrm{PGF}_{2 \alpha}$ produced by the uterus towards the end of the oestrous cycle is responsible for causing luteolysis in a number of mammalian species, including guinea-pigs (Poyser, 1995). Oestradiol treatment of ovariectomized guinea-pigs maintained on progesterone results in an increase in $\mathrm{PGF}_{2 \alpha}$ output from the uterus (Blatchley and Poyser, 1974; Poyser, 1983a). During the oestrous cycle in guinea-pigs, increased secretion of oestradiol from the ovary occurs after day 10 (Joshi et al., 1973), which precedes by 1 day the increase in $\mathrm{PGF}_{2 \alpha}$ secretion by the uterus (Blatchley et al., 1972; Earthy et al., 1975; Antonini et al., 1976). Increased production of $\mathrm{PGF}_{2 \alpha}$ by the uterus and the subsequent decrease in progesterone output from the ovary are prevented by treating guinea-pigs from day 11 to day 14 of the oestrous cycle with the oestrogen receptor antagonist, $\mathrm{ICl} 182780$, or the progesterone receptor antagonist, onapristone (Poyser, 1993). Oestradiol acting on a progesterone-primed uterus is therefore the physiological stimulus for increased $\mathrm{PGF}_{2 \alpha}$ production by the guinea-pig uterus (particularly the endometrium), particularly as oxytocin does not have a stimulatory effect on endometrial $\mathrm{PGF}_{2 \alpha}$ synthesis in guinea-pigs or affect the

* Present address: Cardiovascular Biology and Medicine, New Hunt's House, King's College London, Guy's Campus, London SE1 1 UL, UK

${ }^{+}$Correspondence

Email: Norman.Poyser@ed.ac.uk duration of the oestrous cycle when administered to this species (Donovan, 1961; Poyser and Brydon, 1983; Riley and Poyser, 1987a). The epithelial cells, rather than the stromal cells, are the main type of cell responsible for synthesizing $\mathrm{PGF}_{2 \alpha}$ in guinea-pig endometrium (Naderali and Poyser, 1996a; Bracken et al., 1997).

One of the main steps in the synthesis of $\mathrm{PGF}_{2 \alpha}$ is the conversion of arachidonic acid to $\mathrm{PGH}_{2}$ by prostaglandin $\mathrm{H}$ synthase (PGHS), of which there are two isoforms: PGHS-1 (constitutive form) and PGHS-2 (inducible form) (Smith et al., 1996). However, PGHS-2 is the predominant form in guinea-pig endometrium during the oestrous cycle and very little PGHS-1 is present (Naderali and Poyser, 1994, 1996b; Bracken et al., 1997). In ovariectomized guinea-pigs, oestradiol, but not progesterone, causes an increase in the activity of PGHS in the endometrium (Naylor and Poyser, 1975; Poyser, 1983b). This action of oestradiol is due solely to an increase in the expression of PGHS-2 mRNA (Bracken et al., 1997). During the oestrous cycle of guinea-pigs, the concentration of PGHS in the endometrium increases from day 12 (which is after the increase in output of oestradiol from the ovary) and is prevented by treatment with $\mathrm{ICl}$ 182780 (Poyser, 1972, 1983b, 1993). However, there is no evidence that oestradiol stimulates PGHS-2 synthesis directly. Instead, PGHS-2 is induced by inflammatory mediators, such as growth factors and cytokines (Smith et al., 1996), and various growth factors are produced by the uterus (Brigstock et al., 1989). Epidermal growth factor (EGF) and interleukin 1 (IL-1) increase the concentrations of prostaglandins and PGHS-2 in endometrial cells from the 
uterus of both mice and rats primed for the decidual cell reaction (Paria et al., 1991; Jacobs and Carson, 1993; Jacobs et al., 1994; Bany and Kennedy, 1995a,b, 1997, 1999). In the mouse uterus IL-1 concentrations are highest on the day of implantation and oestradiol stimulates EGF production; therefore, EGF or IL-1 may mediate the action of oestradiol in stimulating increased endometrial prostaglandin production at the time of implantation in rodents (Huet-Hudson et al., 1990; De et al., 1993). EGF and IL-1 also stimulate prostaglandin production by human decidual cells, and IL-1 increases the expression of PGHS-2 mRNA (Mitchell, 1991; Kennard et al., 1995). In addition to growth factors and cytokines, there is evidence that nitric oxide can stimulate prostaglandin synthesis (Di Rosa et al., 1996; Maccarrone et al., 1997; Goodwin et al., 1999) and, in uterine tissues, this may be achieved by activating PGHS-2 (Swaisgood et al., 1997).

Although oestradiol increases the concentration of PGHS-2 in the guinea-pig endometrium, this increase alone is not sufficient to increase uterine $\mathrm{PGF}_{2 \alpha}$ output (Poyser, $1983 a, b)$. Progesterone priming of the uterus is also required (Poyser, 1983a). The release of arachidonic acid from phospholipids by the action of phospholipase $A_{2}$ $\left(\mathrm{PLA}_{2}\right)$ is the rate-limiting step in $\mathrm{PGF}_{2 \alpha}$ production by the guinea-pig uterus (Poyser, 1985a, 1987; Johnson and Poyser, 1991; Norman and Poyser, 2000). Consequently, any local factor produced by oestradiol not only has to increase the uterine concentration of PGHS-2 in order to increase the amount of $\mathrm{PGF}_{2 \alpha}$ produced in the long term, but must also stimulate arachidonic acid release in the short term to provide the precursor for prostaglandin synthesis. Therefore, the aim of the present study was to investigate whether EGF, IL-1 and nitric oxide in the short term are able to stimulate prostaglandin production by the guinea-pig uterus superfused in vitro, and thereby become possible candidates for mediating the action of oestradiol in stimulating $\mathrm{PGF}_{2 \alpha}$ production in vivo.

\section{Materials and Methods}

\section{Materials}

Epidermal growth factor, sodium nitroprusside and IL-1 $\beta$ were purchased from Sigma Chemical Co. (Poole).

\section{Methods}

Thirty virgin guinea-pigs (Dunkin Hartley) weighing 600-900 g were examined daily and, when the vagina was open, a vaginal smear was obtained and examined under a microscope. Day 1 of the oestrous cycle was taken as the day preceding the post-ovulatory influx of leucocytes when cornification is at a maximum. After at least two oestrous cycles of normal duration (16-18 days), the guinea-pigs were used on day 7 of the oestrous cycle. The animals were killed by stunning and an incision in the neck, and the uterus from each animal was removed. The uterus was divided into the two uterine horns, and each horn was opened by longitudinal incision and superfused with Krebs' solution $(5 \mathrm{ml} \mathrm{min}-1)$ at $37^{\circ} \mathrm{C}$ as described by Poyser and Brydon (1983). In all studies, each uterine horn was superfused initially for a 'settling period' of 60 min before the experiments began. In the first series of experiments, samples of superfusate were collected for $10 \mathrm{~min}$ periods for the next $80 \mathrm{~min}$ (that is, eight samples from each uterine horn). During the superfusion of one uterine horn from each animal, EGF $\left(100 \mathrm{ng} \mathrm{ml}^{-1}\right)$, sodium nitroprusside $\left(50 \mu \mathrm{mol} \mathrm{I}^{-1}\right)$ or IL-1 $\beta$ (10 or $20 \mathrm{ng} \mathrm{ml}^{-1}$ ) was present in the Krebs' solution during the collection of samples four and five of the eight samples obtained. The other uterine horn from each animal was untreated. In an additional experiment, both uterine horns from each guinea-pig were superfused with Krebs' solution from which the calcium chloride had been omitted (that is calcium-depleted Krebs' solution). EGF $\left(100 \mathrm{ng} \mathrm{ml}^{-1}\right)$ was present in this solution during the collection of samples four and five from one of the uterine horns. The amounts of $\mathrm{PGF}_{2 \alpha}, \mathrm{PGE}_{2}$ and 6-keto-PGF $1 \alpha$ in each sample of superfusate were measured by radioimmunoassay.

In a second series of experiments, the contractile activity of one uterine horn from each animal was recorded isotonically for $30 \mathrm{~min}$ before and after treatment, and for $20 \mathrm{~min}$ during treatment with sodium nitroprusside $\left(50 \mu \mathrm{mol} \mathrm{I}^{-1}\right)$, using a Washington Isotonic Lever Transducer T2 connected to a Servogor 124 (Goerz) pen recorder. This procedure was also performed on the other uterine horn from which the endometrium had been removed by a technique described by Leaver and Poyser (1981), leaving just the intact myometrium. Contractile activity $\left(\mathrm{cm}^{2} \mathrm{~min}^{-1}\right)$ was calculated as the area between the contraction curves and baseline (that is area under the curve) before, during and after treatment divided by the period for which the contractions were recorded.

\section{Assays}

Immediately after collection, the $\mathrm{pH}$ of each sample of superfusate was reduced to 4.0 with $\mathrm{HCl}$ and the prostaglandins were extracted by shaking twice with $50 \mathrm{ml}$ ethyl acetate. The two ethyl acetate fractions were combined and evaporated to dryness on a rotary evaporator at $50^{\circ} \mathrm{C}$ (Poyser, 1987). Each dried extract was dissolved in $10 \mathrm{ml}$ ethyl acetate and stored at $-20^{\circ} \mathrm{C}$. The amounts of $\mathrm{PGF}_{2 \alpha}$ $\mathrm{PGE}_{2}$ and 6-keto-PGF ${ }_{1 \alpha}$ in each sample were measured by radioimmunoassay using antibodies raised in this laboratory; crossreactivities of the antibodies have been reported elsewhere (Poyser, 1987). The inter- and intraassay coefficients of variation were $<12 \%$. The detection limit was $0.5-0.8 \mathrm{pg}$ prostaglandin per $100 \mathrm{mg}$ tissue per $\min$.

\section{Statistical analysis}

Changes in the outputs of prostaglandins with time were analysed by Duncan's multiple-range test. Other comparisons were made using the Student's $t$ test. 


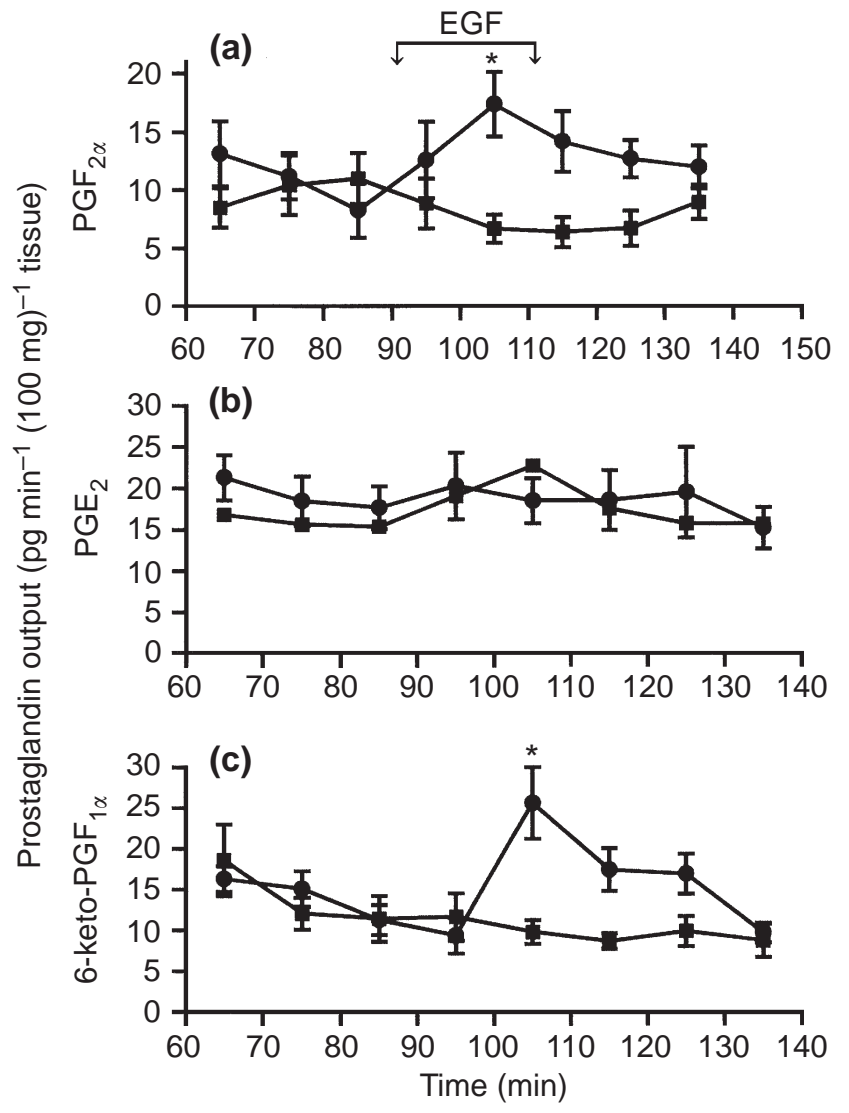

Fig. 1. Mean ( $\pm \mathrm{SEM}, n=5$ ) outputs of (a) $\mathrm{PGF}_{2 \alpha^{\prime}}$ (b) $\mathrm{PGE}_{2}$ and (c) 6-keto-PGF ${ }_{1 \alpha}$ from day 7 guinea-pig uterus superfused in vitro in the presence $(\mathbf{O})$ and absence $(\mathbf{\square})$ of epidermal growth factor (EGF). *Significantly $(P<0.05)$ higher than corresponding values before treatment with EGF.

\section{Results}

\section{Prostaglandin output}

EGF significantly $(P<0.05)$ increased the outputs of $\mathrm{PGF}_{2 \alpha}$ and 6-keto-PGF $1 \alpha$, but not of $\mathrm{PGE}_{2}$, from the day 7 guinea-pig uterus superfused in vitro (Fig. 1). After the omission of calcium from the superfusing solution to investigate whether extracellular calcium was necessary for these increases, EGF still significantly $(P<0.05)$ increased the output of $\mathrm{PGF}_{2 \alpha}$, but had no significant effect on the output of 6-keto-PGF ${ }_{1 \alpha}$ from the day 7 uterus. The output of $\mathrm{PGE}_{2}$ was still not increased (Fig. 2). Sodium nitroprusside also significantly $(P<0.05)$ increased the outputs of $\mathrm{PGF}_{2 \alpha}$ and 6-keto-PGF ${ }_{1 \alpha}$, but not of $\mathrm{PGE}_{2}$, from the day 7 guineapig uterus superfused in calcium-containing Krebs' solution (Fig. 3). The outputs (ng $\mathrm{min}^{-1}(100 \mathrm{mg})^{-1}$ tissue) from the superfused guinea-pig uterus of $\mathrm{PGF}_{2 \alpha}, \mathrm{PGE}_{2}$ and 6-keto-PGF ${ }_{1 \alpha}$ before treatment with IL-1 $\beta\left(20 \mathrm{ng} \mathrm{ml}^{-1}\right)$ were $0.014 \pm 0.002,0.007 \pm 0.002$ and $0.021 \pm 0.005$, respectively, and during treatment were $0.012 \pm 0.002,0.007 \pm$ 0.001 and $0.016 \pm 0.002$, respectively. Therefore, IL-1 $\beta$ (20 $\mathrm{ng} \mathrm{ml}^{-1}$ ) had no significant effects on the outputs of
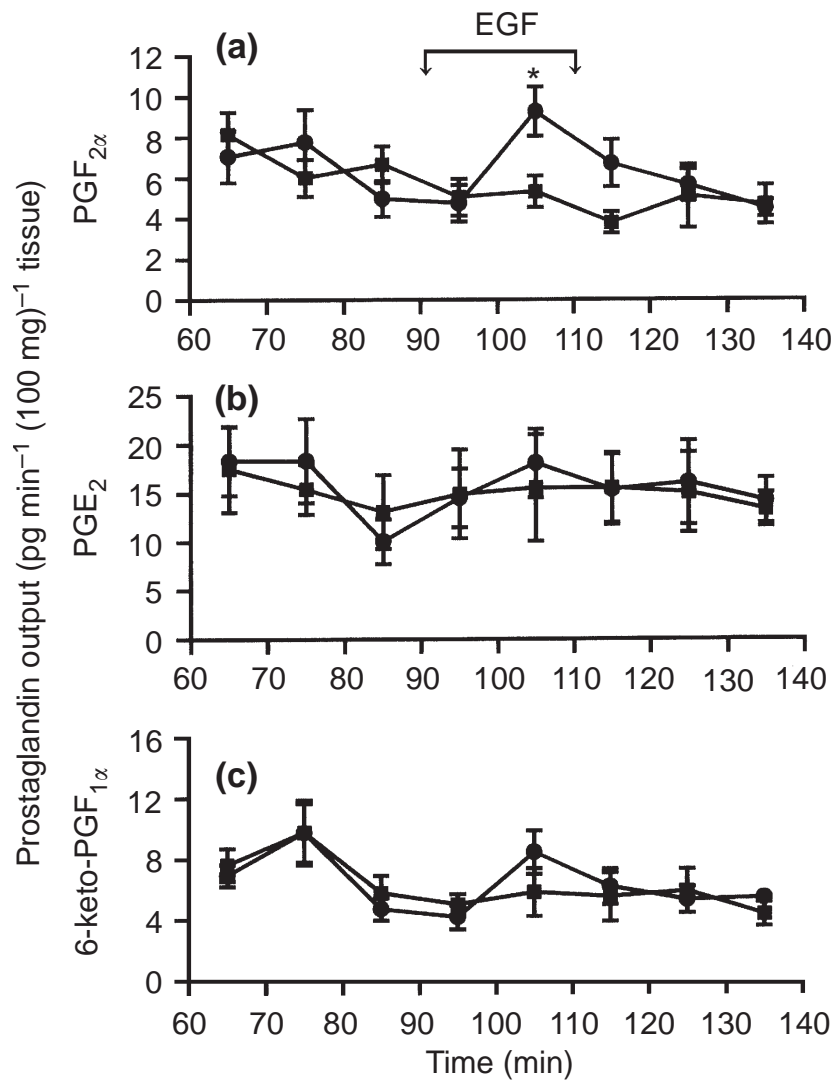

Fig. 2. Mean ( $\pm \mathrm{SEM}, n=5$ ) outputs of (a) $\mathrm{PGF}_{2 \alpha^{\prime}}$ (b) $\mathrm{PGE}_{2}$ and (c) 6-keto-PGF ${ }_{1 \alpha}$ from day 7 guinea-pig uterus superfused in calciumdepleted Krebs' solution in vitro in the presence $(-)$ and absence 口) of epidermal growth factor (EGF). *Significantly $(P<0.05)$ higher than corresponding values before treatment with EGF.

prostaglandins from the day 7 guinea-pig uterus. Similar findings were obtained with the lower dose $\left(10 \mathrm{ng} \mathrm{ml}^{-1}\right)$ of IL-1 $\beta$.

\section{Contractile activity}

The day 7 guinea-pig uterus showed low spontaneous activity when superfused in vitro. Sodium nitroprusside significantly $(P<0.05)$ increased this contractile activity by mainly increasing the frequency of the contractions. After cessation of the sodium nitroprusside treatment, the spontaneous activity of the uterus was reduced. Similar findings were obtained if the myometrium alone was used (Fig. 4).

\section{Discussion}

The basal outputs of prostaglandins from day 7 guinea-pig uterus superfused in vitro were similar to those obtained by Naderali and Poyser (1994). However, these outputs varied twofold among the experiments. Such a variation was also reported by Naderali and Poyser (1994) and is probably due to inter-experimental variation. In the present study, the 

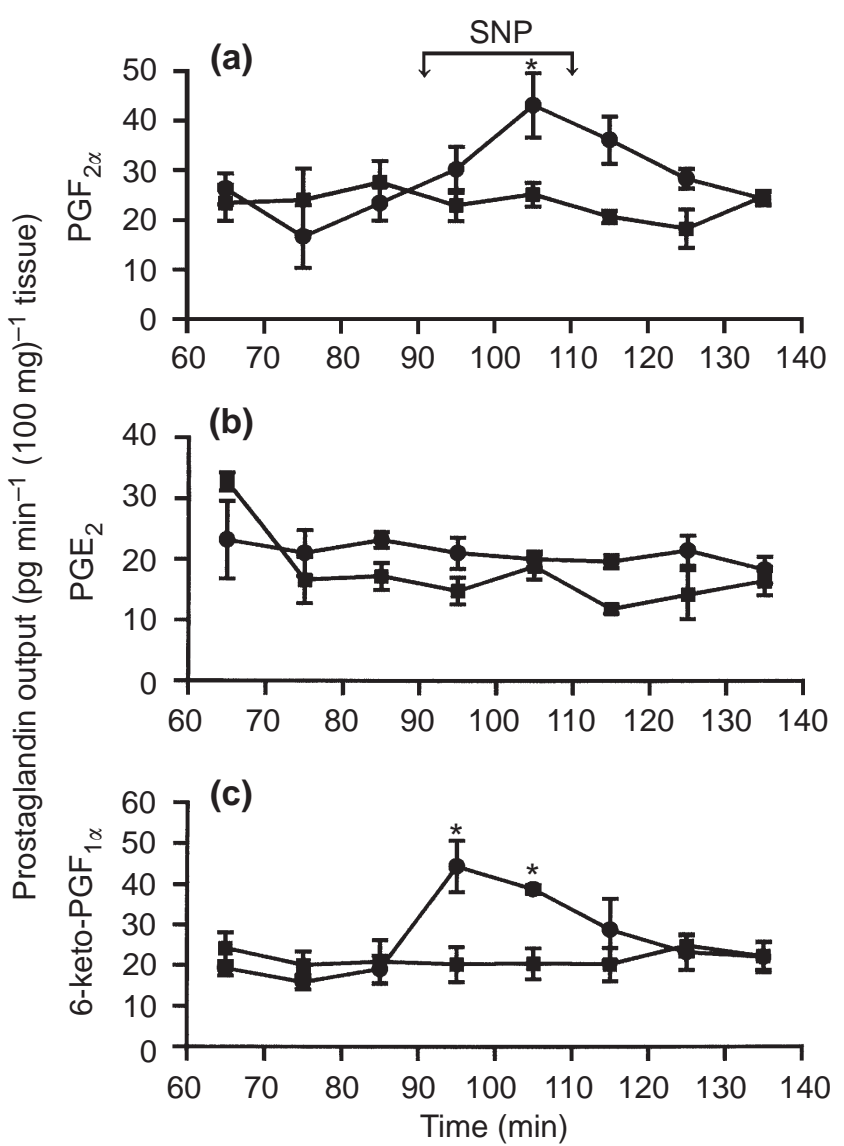

Fig. 3. Mean ( $\pm \mathrm{SEM}, n=5$ ) outputs of (a) $\mathrm{PGF}_{2 \alpha^{\prime}}$ (b) $\mathrm{PGE}_{2}$ and (c) 6keto-PGF ${ }_{1 \alpha}$ from day 7 guinea-pig uterus superfused in vitro in the presence $(\mathbf{O})$ and absence ( $)$ of sodium nitroprusside (SNP). *Significantly $(P<0.05)$ higher than corresponding values before treatment with SNP.

outputs of $\mathrm{PGF}_{2 \alpha}$ and 6-keto-PGF $1 \alpha$ were increased 2.1- and 2.3 -fold, respectively, by EGF treatment. The output of $\mathrm{PGE}_{2}$ was unaffected by EGF. PGF $2 \alpha$ and 6-keto-PGF $1 \alpha$ are the major prostaglandins synthesized by the endometrium and myometrium, respectively (Poyser, 1983b), although the endometrium also synthesizes and secretes 6-ketoPGF $_{1 \alpha}$ (Riley and Poyser, 1987a,b). Calcium is necessary for the stimulation of prostaglandin production by the guineapig uterus (Poyser, 1985a,b; Riley and Poyser, 1987b). However, EGF increased the output of $\mathrm{PGF}_{2 \alpha}$ from the guinea-pig uterus 1.9-fold in the absence of extracellular calcium, indicating that the calcium involved in the action of EGF has to be of intracellular origin. Notwithstanding, EGF failed to stimulate the output of 6-keto-PGF $1 \alpha$ from the guinea-pig uterus in the absence of extracellular calcium, indicating that extracellular calcium is required for this increase in $\mathrm{PGI}_{2}$ production and, hence, 6-keto- $\mathrm{PGF}_{1 \alpha}$ output. These findings are in agreement with the results of a study by Poyser (1984) in which the high output of $\mathrm{PGF}_{2 \alpha}$ from day 15 (compared with day 7) guinea-pig uterus

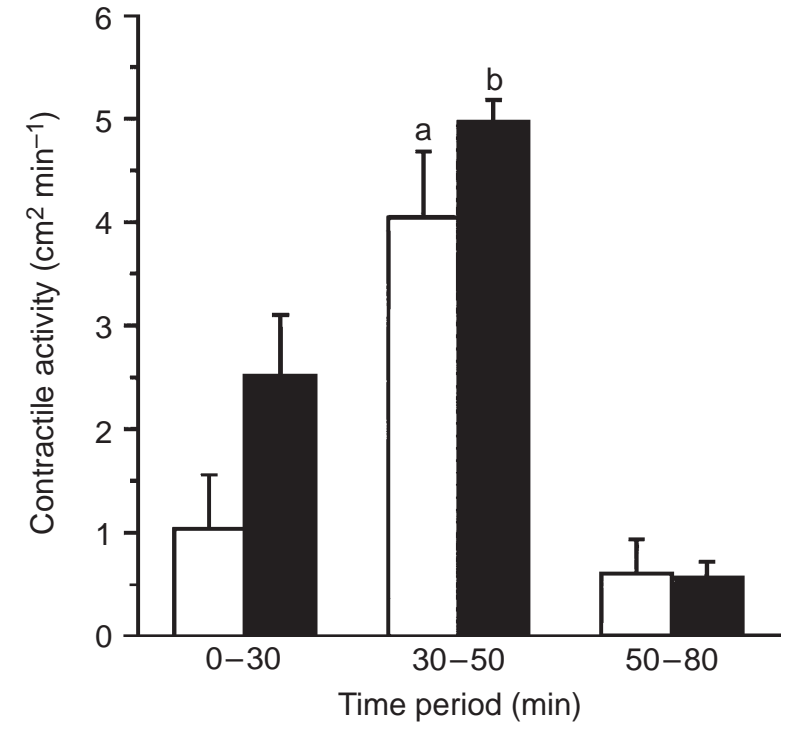

Fig. 4. Contractile activity (mean $\pm \operatorname{SEM}, n=5$ ) of day 7 guinea-pig uterus $(\square)$ and myometrium ( $\square$ ) superfused in vitro before (0-30 min), during (30-50 min) and after (50-80 min) treatment with sodium nitroprusside (SNP). abSignificantly $(P<0.05)$ higher than corresponding values before and after treatment with SNP.

superfused in vitro was not reduced by the absence of extracellular calcium, whereas the output of 6-keto-PGF $1 \alpha$ was decreased by $50 \%$ in calcium-depleted medium. These findings also support the view that the production of $\mathrm{PGF}_{2 \alpha}$ and 6-keto-PGF ${ }_{1 \alpha}$ by guinea-pig uterus is controlled by independent processes (Riley and Poyser, 1987a, 1989, 1990). As EGF is known to stimulate PLA 2 activity and release arachidonic acid for prostaglandin synthesis (Sato et al., 1997; Bany et al., 1999), that findings from the present study indicate that EGF could mediate the stimulatory action of oestradiol on uterine $\mathrm{PGF}_{2 \alpha}$ production in the guinea-pig.

The outputs of $\mathrm{PGF}_{2 \alpha}, \mathrm{PGE}_{2}$ and 6-keto-PGF $\mathrm{PG}_{1 \alpha}$ from guinea-pig uterus were not affected by IL- $1 \beta$. Therefore, it is unlikely that IL-1 $\beta$ mediates the stimulation of uterine $\mathrm{PGF}_{2 \alpha}$ synthesis by oestradiol in guinea-pigs. Likewise, a study in cows indicated that IL-1 is not involved in increased $\mathrm{PGF}_{2 \alpha}$ production by the endometrium at the time of luteolysis (Leung et al., 2001).

The outputs of $\mathrm{PGF}_{2 \alpha}$ and 6-keto-PGF $1 \alpha$ from the day 7 uterus were increased 1.7- and 2.3-fold, respectively, by the nitric oxide donor, sodium nitroprusside. $\mathrm{PGE}_{2}$ output was not affected. Therefore, nitric oxide should also be considered as a possible mediator in the stimulatory action of oestradiol on uterine $\mathrm{PGF}_{2 \alpha}$ production in guinea-pigs. This view is supported by reports that oestradiol stimulates the expression of nitric oxide synthase (NOS) types I and III in non-pregnant sheep uterus, and type III in late pregnant rat uterus (Zhang et al., 1999; Yallampalli and Dong, 2000). However, oestradiol inhibits the expression of NOS-II and total nitric oxide production in late pregnant rat uterus by a 
mechanism that may involve the action of $\mathrm{PGF}_{2 \alpha}$ (Dong et al., 1997).

Somewhat surprisingly, sodium nitroprusside increased by almost fourfold the contractile activity of the superfused, day 7 guinea-pig uterus. Contractile activity was increased to a similar extent by sodium nitroprusside acting on the myometrium alone, indicating that the endometrium is not required for this increase in activity. The mechanism by which sodium nitroprusside increases contractile activity is not clear, although it is probably not as a result of increased prostaglandin production. EGF increased the output of prostaglandins from the guinea-pig uterus to a similar extent as sodium nitroprusside but had no effect on the contractile activity of the uterus. Another nitric oxide donor (s-nitrosoL-cysteine) failed to alter the spontaneous activity of nonpregnant and pregnant guinea-pig myometrium, although it reduced the contractions produced by acetylcholine or oxytocin (Kuenzli et al., 1996). These contradictory results may be explained by differences in the methods used. In the study of Kuenzli et al. (1996), the tissue was suspended in an organ bath surrounded by fluid, which allows metabolites to build up and the spontaneous activity to increase. In the present study, the guinea-pig uterus was superfused with Krebs' solution, which continually washes away metabolites and allows only low spontaneous contractile activity. Thus, on the guinea-pig uterus, nitric oxide may increase contractile activity when there is little spontaneous activity but have no effect when the spontaneous activity is high. However, other species may be different in this respect as nitric oxide donors (glyceryl trinitrate and sodium nitroprusside) reduce, but do not abolish, the high spontaneous activity of pregnant human myometrial strips in vitro (Norman et al., 1997; Wetzka et al., 2001). It is assumed that the high NOS-II expression and nitric oxide production by rat uterus during pregnancy is necessary to maintain a quiescent uterus (Dong et al., 1998). Similar studies need to be performed on other species to determine the role of nitric oxide in controlling uterine activity.

Overall, the results of the present study indicate that EGF or nitric oxide may be involved in the biochemical pathways by which oestradiol stimulates increased uterine $\mathrm{PGF}_{2 \alpha}$ in guinea-pigs. In fact, both compounds might be involved, as the stimulation of prostaglandin production by the oestrogenized rat uterus by EGF is apparently dependent on the production of NOS-II and nitric oxide (Ribeiro et al., 1999). EGF activates the mitogen-activated protein (MAP) kinase pathway, and it is known that oestradiol can activate the MAP kinase pathway through mobilization of EGF (Filardo et al., 2000). The activation of cytosolic PLA $\mathrm{P}_{2}$ is dependent on its phosphorylation by the MAP kinase pathway (Leslie, 1997), and the stimulation of $\mathrm{PGF}_{2 \alpha}$ production in the sheep uterus by oxytocin is dependent on the activation of MAP kinases (Burns et al., 2001). Therefore, further study is required to establish the precise mediators and intracellular pathways by which oestradiol acting on a progesterone-primed uterus stimulates the increase in $\mathrm{PGF}_{2 \alpha}$ production necessary for luteolysis in the guinea-pig.

\section{References}

Antonini R, Turner TT and Pauerstein CJ (1976) The hormonal control of the guinea-pig corpus luteum during early pregnancy Fertility and Sterility 27 1322-1325

Bany BM and Kennedy TG (1995a) Interleukin-1 $\alpha$ regulates prostaglandin production and cyclooxygenase activity in sensitized rat endometrial stromal cells in vitro. Biology of Reproduction 53 126-132

Bany BM and Kennedy TG (1995b) Regulation by epidermal growth factor of prostaglandin production and cyclooxygenase activity in sensitized rat endometrial stromal cells Journal of Reproduction and Fertility 104 $57-62$

Bany BM and Kennedy TG (1997) Regulation of cyclooxygenase gene expression in rat endometrial stromal cells: the role of epidermal growth factor Developmental Genetics 21 109-115

Bany BM and Kennedy TG (1999) Role of interleukin 1 in the regulation of cyclooxygenase gene expression in rat endometrial stromal cells Journal of Reproduction and Fertility 115 125-131

Bany BM, Schultz GA and Kennedy TG (1999) Regulation of cytosolic phospholipase $\mathrm{A}_{2}$ in rat endometrial stromal cells: the role of epidermal growth factor Molecular Reproduction and Development 53 335-340

Blatchley FR and Poyser NL (1974) The effect of oestrogen and progesterone on the release of prostaglandins from the uterus of the ovariectomised guinea-pig Journal of Reproduction and Fertility 40 205-209

Blatchley FR, Donovan BT, Horton EW and Poyser NL (1972) The release of prostaglandins and progestin into the utero-ovarian venous blood of guinea-pigs during the oestrous cycle and following oestrogen treatment Journal of Physiology 222 69-88

Bracken KE, Elger W, Jantke I, Nanninga A and Gellersen B (1997) Cloning of guinea-pig cyclooxgenase-2 and 15-hydroxyprostaglandin dehydrogenase deoxyribonucleic acids: steroid-modulated gene expression correlates to prostaglandin $\mathrm{F}_{2 \alpha}$ secretion in cultured endometrial cells Endocrinology 138 237-247

Brigstock DR, Heap RB and Brown KD (1989) Polypeptide growth factors in uterine tissues and secretions Journal of Reproduction and Fertility $\mathbf{8 5}$ 747-758

Burns PD, Mendes JOB, Jr, Yemm RS, Clac CM, Nelson SH and Silvia WJ (2001) Cellular mechanisms by which oxytocin mediates ovine endometrial prostaglandin $F_{2 \alpha}$ synthesis: role of $G_{i}$ protein and mitogenactivated protein kinase Biology of Reproduction 65 1150-1155

De M, Sanford TR and Wood GW (1993) Expression of interleukin 1, interleukin 6 and tumour necrosis factor $\alpha$ in mouse uterus during the peri-implantation period of pregnancy Journal of Reproduction and Fertility 97 83-89

Di Rosa M, Ialenti A, lanaro A and Sautebin L (1996) Interaction between nitric oxide and cyclooxygenase pathways Prostaglandins, Leukotrienes and Essential Fatty Acids $\mathbf{5 4} 229-238$

Dong YL, Dai BS, Singh P and Yallampalli C (1997) Involvement of nitric oxide pathway in prostaglandin $\mathrm{F}_{2 \alpha}$-induced preterm labor in rats American Journal of Obstetrics and Gynecology 177 907-917

Dong YL, Fang L, Gangula PR and Yallampalli C (1998) Regulation of inducible nitric oxide synthase messenger ribonucleic acid expression in pregnant rat uterus Biology of Reproduction 59 933-940

Donovan BT (1961) The role of the uterus in the regulation of the oestrous cycle Journal of Reproduction and Fertility 2 508-510

Earthy M, Bishop C and Flack JD (1975) Progesterone and prostaglandin F concentrations in utero-ovarian venous plasma of cyclic guinea-pigs Journal of Endocrinology $6411 \mathrm{P}-12 \mathrm{P}$

Filardo EJ, Quinn JA, Bland KI and Frackleton AR (2000) Estrogen-induced activation of Erk-1 and Erk-2 requires the G protein-coupled receptor homolog, GPR 30, and occurs via trans-activation of the epidermal growth factor receptor through release of HB-EGF Molecular Endocrinology 14 1649-1660

Goodwin DC, Landino LM and Marnett LJ (1999) Effects of nitric oxide and nitric oxide derived species on prostaglandin endoperoxide synthase and prostaglandin biosynthesis FASEB Journal 13 1121-1136

Huet-Hudson YM, Chakraborty C, De SK, Suzaki Y, Andrews GK and Dey SK (1990) Estrogen regulates the synthesis of epidermal growth factor in mouse uterine epithelial cells Molecular Endocrinology 4 510-523 
Jacobs AL and Carson DD (1993) Uterine epithelial cell secretions of interleukin- $1 \alpha$ induce prostaglandin $\mathrm{E}_{2}\left(\mathrm{PGE}_{2}\right)$ and $\mathrm{PGF}_{2 \alpha}$ secretion by uterine stromal cells in vitro. Endocrinology 132 300-308

Jacobs AL, Hwang D, Julian J and Carlson DD (1994) Regulated expression of prostaglandin endoperoxide synthase-2 by uterine stroma Endocrinology 135 1807-1815

Johnson FA and Poyser NL (1991) Effect of melittin on prostaglandin production by guinea-pig uterus Journal of Reproduction and Fertility 93 $577-583$

Joshi HS, Watson DJ and Labhsetwar AP (1973) Ovarian secretion of oestradiol, oestrone, 20-dihydroprogesterone and progesterone during the oestrous cycle of the guinea-pig Journal of Reproduction and Fertility 35 177-182

Kennard EA, Zimmerman PD, Friedman CI and Kriss DA (1995) Interleukin$1 \alpha$ induces cyclooxygenase in cultured human decidual cells American Journal of Reproductive Immunology 34 65-71

Kuenzli KA, Bradley ME and Buxton ILO (1996) Cyclic GMP-independent effects of nitric oxide on guinea-pig uterine contractility British Journal of Pharmacology 119 737-743

Leaver HA and Poyser NL (1981) Distribution of arachidonic acid and other fatty acids in the lipids of guinea-pig uterus and plasma in relation to uterine prostaglandin synthesis Journal of Reproduction and Fertility $\mathbf{6 2}$ 265-271

Leslie CC (1997) Properties and regulation of cytosolic phospholipase $A_{2}$ Journal of Biological Chemistry 27216 709-16 712

Leung ST, Cheng Z, Sheldrick EL, Derecka K, Flint APF and Wathes DC (2001) The effects of lipopolysaccharide, and interleukins- $1 \alpha,-2$ and -6 on oxytocin receptor expression and prostaglandin production in bovine endometrium Journal of Endocrinology 168 497-508

Maccarrone M, Putti S and Agra AF (1997) Nitric oxide donors activate the cyclooxygenase and peroxidase activities of prostaglandin $\mathrm{H}$ synthase FEBS Letters 1410 470-476

Mitchell MD (1991) The regulation of decidual prostaglandin biosynthesis by growth factors, phorbol esters and calcium Biology of Reproduction 44 871-874

Naderali EK and Poyser NL (1994) The effect of caffeine on prostaglandin output from the guinea-pig uterus British Journal of Pharmacology 113 $103-110$

Naderali EK and Poyser NL (1996a) Factors controlling prostaglandin production by guinea-pig endometrial cells Journal of Reproduction and Fertility 108 321-328

Naderali EK and Poyser NL (1996b) Effect of a selective prostaglandin H synthase-2 inhibitor (NS-398) on prostaglandin production by the guinea-pig uterus Journal of Reproduction and Fertility 108 75-80

Naylor B and Poyser NL (1975) The effect of oestradiol and progesterone on the in vitro production of prostaglandin $\mathrm{F}_{2 \alpha}$ by the guinea-pig uterus British Journal of Pharmacology 55 229-232

Norman SJ and Poyser NL (2000) Effects of inhibitors of arachidonic acid turnover on the production of prostaglandins by the guinea-pig uterus Journal of Reproduction and Fertility 118 181-186

Norman JE, Ward LM, Martin W, Cameron AD, McGrath JC, Greer IA and Cameron IT (1997) Effects of cGMP and the nitric oxide donors glyceryl trinitrate and sodium nitroprusside on contractions in vitro of isolated myometrial tissue from pregnant women uterus Journal of Reproduction and Fertility 110 249-254

Paria BC, Das SK, Gupta A and Dey SK (1991) Reversal of indomethacininduced inhibition of implantation in the mouse by epidermal growth factor Prostaglandins 42 191-199

Poyser NL (1972) Production of prostaglandins by the guinea-pig uterus Journal of Endocrinology 54 147-159

Poyser NL (1983a) Effect of treating ovariectomized guinea-pigs with estradiol and progesterone on basal and A23187-stimulated release of prostaglandins from the guinea-pig uterus superfused in vitro. Prostaglandins, Leukotrienes and Medicine 11 345-360

Poyser NL (1983b) Differential stimulation of prostaglandin and thromboxane synthesizing capacities in the guinea-pig uterus and ovary Prostaglandins, Leukotrienes and Medicine 10 163-177
Poyser NL (1984) Effects of using calcium-free Krebs' solution on basal and A23187-stimulated prostaglandin output from the day 15 guinea-pig uterus superfused in vitro. Prostaglandins, Leukotrienes and Medicine $13259-269$

Poyser NL (1985a) Effect of trifluoperazine, a calmodulin antagonist, on prostaglandin output from the guinea-pig uterus Journal of Reproduction and Fertility 73 295-303

Poyser NL (1985b) Effects of TMB-8, an intracellular calcium antagonist, and W-7, a calmodulin antagonist, on prostaglandin output from the guinea-pig uterus Journal of Reproduction and Fertility 75 223-230

Poyser NL (1987) Effects of various factors on prostaglandin synthesis by the guinea-pig uterus Journal of Reproduction and Fertility 81 269-276

Poyser NL (1993) Effects of onapristone, tamoxifen and ICI 182780 on uterine prostaglandin production and luteal function in non-pregnant guinea-pigs Journal of Reproduction and Fertility 98 307-312

Poyser NL (1995) The control of prostaglandin production by the endometrium in relation to luteolysis and menstruation Prostaglandins, Leukotrienes and Essential Fatty Acids 53 147-195

Poyser NL and Brydon LJ (1983) Prostaglandin release from the guinea-pig uterus superfused in vitro. Effect of stage of estrous cycle, progesterone, estradiol, oxytocin and A23187 Prostaglandins 25 443-456

Ribeiro ML, Martinez SP, Farina M, Ogundo D, Gimeno $M$ and Franchi A (1999) The effect of epidermal growth factor on prostaglandin synthesis of oestrogenized rat uterus is mediated by nitric oxide Prostaglandins, Leukotrienes and Essential Fatty Acids 61 353-358

Riley SC and Poyser NL (1987a) Effects of oestradiol, progesterone, hydrocortisone and oxytocin on prostaglandin output from the guineapig endometrium maintained in tissue culture Prostaglandins 34 535-552

Riley SC and Poyser NL (1987b) Prostaglandin production by the guinea-pig endometrium: is calcium necessary? Journal of Endocrinology 113 463-471

Riley SC and Poyser NL (1989) Is protein synthesis necessary for prostaglandin production by guinea-pig endometrium? Journal of Reproduction and Fertility 86 73-89

Riley SC and Poyser NL (1990) Is the inhibitory effect of progesterone on endometrial prostaglandin $\mathrm{F}_{2 \alpha}$ production due to an inhibition of protein synthesis? Prostaglandins, Leukotrienes and Essential Fatty Acids 39 189-196

Sato T, Nakajima H, Fujio K and Mari Y (1997) Enhancement of prostaglandin $E_{2}$ production by epidermal growth factor requires the coordinate activation of cytosolic phospholipase $\mathrm{A}_{2}$ and cyclooxygenase2 in human squamos carcinoma A431 cells Prostaglandins 53 355-369

Smith WL, Garavito RM and DeWitt DL (1996) Prostaglandin endoperoxide $\mathrm{H}$ synthases (cyclooxygenases)- 1 and -2 Journal of Biological Chemistry 27133 157-33 160

Swaisgood CM, Zu HX, Perkins DJ, Wu SC, Garver CL, Zimmerman PD, Iams JD and Kriss DA (1997) Coordinate expression of inducible nitric oxide synthase and cyclooxygenase- 2 genes in uterine tissues of endotoxin-treated pregnant mice American Journal of Obstetrics and Gynecology 177 1253-1262

Wetzka B, Schafer WR, Stehmans A and Zahradnik HP (2001) Effects of nitric oxide donors on the contractility and prostaglandin synthesis of myometrial strips from pregnant and non-pregnant women Gynecological Endocrinology 15 34-42

Yallampalli C and Dong YL (2000) Estradiol-17 $\beta$ inhibits nitric oxide synthase (NOS)-II and stimulates (NOS)-III gene expression in the rat uterus Biology of Reproduction 63 34-41

Zhang J, Massmann GA, Mirabile CP and Figuera JP (1999) Non-pregnant sheep uterine type I and type III nitric oxide synthase expression is differentially regulated by estrogen Biology of Reproduction $\mathbf{6 0}$ 1198-1203

Received 7 March 2002.

First decision 18 April 2002.

Accepted 26 April 2002. 